\title{
NICKEL(II) COMPLEX CONTAINING 5,5'-DIMETHYL-2,2'-BIPYRIDINE: CRYSTAL STRUCTURE AND LUMINESCENT PROPERTIES
}

\author{
A. Abedi ${ }^{1}$, E. Saemian ${ }^{1}$, V. Amani ${ }^{2}$ \\ ${ }^{1}$ Department of Chemistry, North Tehran Branch, Islamic Azad University, P.O. Box: 19585-936, Tehran, Iran \\ E-mail: anita_abedi@yahoo.com \\ ${ }^{2}$ Department of Chemistry, Yadegar-e-Imam Khomeini (RAH) Branch, Islamic Azad University, Tehran, Iran
}

Received April, 28, 2014

[Ni(5,5'-dmbipy) $\left.)_{2} \mathrm{Cl}_{2}\right] \cdot 3 \mathrm{H}_{2} \mathrm{O}(\mathbf{1})$ complex was obtained from the reaction of $\mathrm{NiCl}_{2} \cdot 6 \mathrm{H}_{2} \mathrm{O}$ with 5,5'-dimethyl-2,2'-bipyridine (5,5'-dmbipy) in a mixture of $\mathrm{CH}_{3} \mathrm{OH} / \mathrm{CH}_{3} \mathrm{CN}$. This complex was characterized by elemental analysis, IR, UV-Vis and luminescence spectroscopy, and its structure was determined by the single-crystal diffraction method. The Ni atom has a distorted octahedral coordination by four $\mathrm{N}$ atoms from two 5,5'-dmbipy ligands and two $\mathrm{Cl}^{-}$anions.

DOI: $10.15372 / \mathrm{JSC} 20150813$

K e y w o r d s: nickel(II), 5,5'-dimethyl-2,2'-bipyridine, crystal structure, luminescent properties.

\section{INTRODUCTION}

Nickel, a group 10 element, has the electronic configuration $3 d^{8}$ and exists chiefly in the +2 oxidation state. However, nickel compounds in the other oxidation states $-1,0,+1,+3,+4$ are also known. $\mathrm{Ni}^{2+}$ generally forms octahedral and square planar complexes [1]. During last decade several nickel(II) complexes with $\mathrm{N}$ donor ligands were reported and were characterized by spectroscopy and $\mathrm{X}$-ray diffraction method [2-8]. The nickel(II) complexes with $\mathrm{N}$ donor ligands are interest owing to their importance for catalysts [ 9,10 ]. 5,5'-Dimethyl-2,2'-bipyridine (5,5'-dmbipy) is a good bidentate ligand, and numerous complexes have been prepared with it, such as those of iron [11], platinum [12 ], vanadium [13 ], lead [14], mercury [15], gold [16], cadmium [17], zinc [18 ], indium [19], thallium [20] and rhenium [21 ]. We report herein the synthesis, characterization and crystal structure of a new nickel (II) complex with chloride and 5,5'-dimethyl-2,2'-bipyridine. It is notable that complex 1 is the first complex containing chloride and 5,5'-dimethyl-2,2'-bipyridine ligand, and the crystal structure of $\left[\mathrm{Ni}\left(5,5^{\prime} \text {-dmbipy }\right)_{2}\left(\mathrm{~N}_{3}\right)_{2}\right] \cdot \mathrm{H}_{2} \mathrm{O}$ has been reported previously [22].

\section{EXPERIMENTAL}

Materials and physical methods. All chemicals were purchased from Merck and Aldrich. Infrared spectra $\left(4000-250 \mathrm{~cm}^{-1}\right)$ of solid samples were taken as $1 \%$ dispersion in CsI pellets using a Shimadzu-470 spectrometer. Elemental analysis was performed using a Heraeus CHN-O Rapid analyzer. Melting point was obtained with a Kofler Heizbank Rechart type 7841 melting point apparatus, UV-Vis spectra were recorded on a Specord 5600 spectrometer using a $1 \mathrm{~cm}$ path length cell in methanol at room temperature, luminescence spectra were recorded on a Perkin Elmer LS45 using a $1 \mathrm{~cm}$ path length.

(C) Abedi A., Saemian E., Amani V., 2015 
Synthesis of $\left[\mathbf{N i}\left(\mathbf{5}, 5^{\prime} \text {-dmbipy }\right)_{2} \mathbf{C l}_{\mathbf{2}}\right] \cdot \mathbf{3} \mathbf{H}_{\mathbf{2}} \mathrm{O}$ (1). A solution of 5,5'-dimethyl-2,2'-bipyridine $(0.56 \mathrm{~g}, 3.00 \mathrm{mmol})$ in acetonitrile $(10 \mathrm{ml})$ was added to a solution of $\mathrm{NiCl}_{2} \cdot 6 \mathrm{H}_{2} \mathrm{O}(0.36 \mathrm{~g}, 1.50 \mathrm{mmol})$ in methanol $(15 \mathrm{ml})$ and the resulting green solution was stirred for $30 \mathrm{~min}$ at $45^{\circ} \mathrm{C}$. After one week, green prismatic crystals of 1 were isolated (yield $0.63 \mathrm{~g}, 76 \%, \mathrm{~m} . \mathrm{p} .>300{ }^{\circ} \mathrm{C}$ ). IR $\left(\mathrm{CsI}, \mathrm{cm}^{-1}\right.$ ): $3378 \mathrm{br}, 3045 \mathrm{w}, 2940 \mathrm{w}, 1627 \mathrm{~s}, 1479 \mathrm{~s}, 1392 \mathrm{~m}, 1315 \mathrm{w}, 1244 \mathrm{~s}, 1159 \mathrm{~m}, 1051 \mathrm{~s}, 996 \mathrm{w}, 839 \mathrm{~s}, 732 \mathrm{~m}$, $643 \mathrm{~m}, 581 \mathrm{w}, 512 \mathrm{w}, 427 \mathrm{~m}, 319 \mathrm{~m}, 264 \mathrm{~m}$. UV-Vis: $\lambda_{\max }\left(\mathrm{CH}_{3} \mathrm{OH}, \mathrm{nm}\right), 253,305,317,550,960$. Anal. Calcd. (\%) for $\mathrm{C}_{24} \mathrm{H}_{30} \mathrm{Cl}_{2} \mathrm{~N}_{4} \mathrm{NiO}_{3}$ : C 52.21, H 5.43, N 10.14. Found (\%): C 51.81, H 5.39, N 10.06.

Crystallographic data collection and structure determination. The X-ray diffraction measurements were made on a Bruker APEX II CCD area detector diffractometer at $298 \mathrm{~K}$ (MoK $K_{\alpha}$ radiation, graphite monochromator, $\lambda=0.71073 \AA$ ). The structure of 1 was solved by SHELX-97 and an absorption correction was done using the SADABS programs [23 ]. Data collection, cell refinement, and data reduction were done by APEX II, SAINT, SHELXTL, PLATON, and MERCURY [23-26 ].

\section{RESULT AND DISCUSSION}

Synthesis and characterization. Complex 1 was obtained by the reaction of one equivalent of $\mathrm{NiCl}_{2} \cdot 6 \mathrm{H}_{2} \mathrm{O}$ with two equivalent of 5,5'-dimethyl-2,2'-bipyridine in a mixture of $\mathrm{CH}_{3} \mathrm{OH} / \mathrm{CH}_{3} \mathrm{CN}$ at $45^{\circ}$.

Spectroscopic characterization of $\left[\mathrm{Ni}\left(5,5^{\prime}-\mathbf{d m b i p y}\right)_{2} \mathrm{Cl}_{2}\right] \cdot 3 \mathrm{H}_{2} \mathrm{O}$ (1). IR absorptions of $\mathbf{1}$ are listed in the experimental section and contain several bands between $500 \mathrm{~cm}^{-1}$ and $3100 \mathrm{~cm}^{-1}$, which are related to the hetero aromatic ring modes $\mathrm{C}-\mathrm{H}, \mathrm{C}=\mathrm{C}, \mathrm{C}=\mathrm{N}, \mathrm{C}-\mathrm{C}$, and $\mathrm{C}-\mathrm{N}[12,27-30]$. These bands are shifted to higher frequencies upon coordination in complex of $\mathbf{1}$ [12, 27-30]. This shift to higher frequencies upon coordination has been observed for bipyridine and its derivatives [ 12 , $27-30$ ], and can be explained by changing the conformation of the free ligand from anti in a free ligand to syn orientation in the complexed state. The vibration bands around $3045 \mathrm{~cm}^{-1}$ and $2940 \mathrm{~cm}^{-1}$ are assigned to $v\left(\mathrm{C}-\mathrm{H}_{\mathrm{cycle}}\right)$ and $v\left(\mathrm{C}-\mathrm{H}_{\mathrm{Me}}\right)$, respectively. The broad band near $3378 \mathrm{~cm}^{-1}$ can be assigned to $v(\mathrm{O}-\mathrm{H})$ vibrations [28]. Far infrared spectrum of complex 1 was recorded between $400 \mathrm{~cm}^{-1}$ and $260 \mathrm{~cm}^{-1}$. The $\mathrm{Ni}-\mathrm{N}$ and $\mathrm{Ni}-\mathrm{Cl}$ stretching vibrations appear at $264 \mathrm{~cm}^{-1}$ and $319 \mathrm{~cm}^{-1}$, respectively [28].

UV-Vis spectrum was recorded in the $200-1100 \mathrm{~nm}$ range in methanol. The intense bands at higher energy near-UV region, $253 \mathrm{~nm}, 305 \mathrm{~nm}$, and $317 \mathrm{~nm}$, are assigned to intra-ligand $\pi^{*} \rightarrow \pi$ transitions of 5,5'-dmbipy. The visible and near IR regions also contain two broad bands with low intensity absorbance at $550 \mathrm{~nm}$ and $960 \mathrm{~nm}$, which are assigned to $d-d$ transition [3, 31 ] (Fig. 1).

The luminescence emission spectra $\left(\lambda_{\mathrm{ex}}=315 \mathrm{~nm}\right)$ of 5,5'-dmbipy and 1 were obtained in DMSO at room temperature and the results are displayed in Fig. 2. The maximum emission of 5,5'-dmbipy at
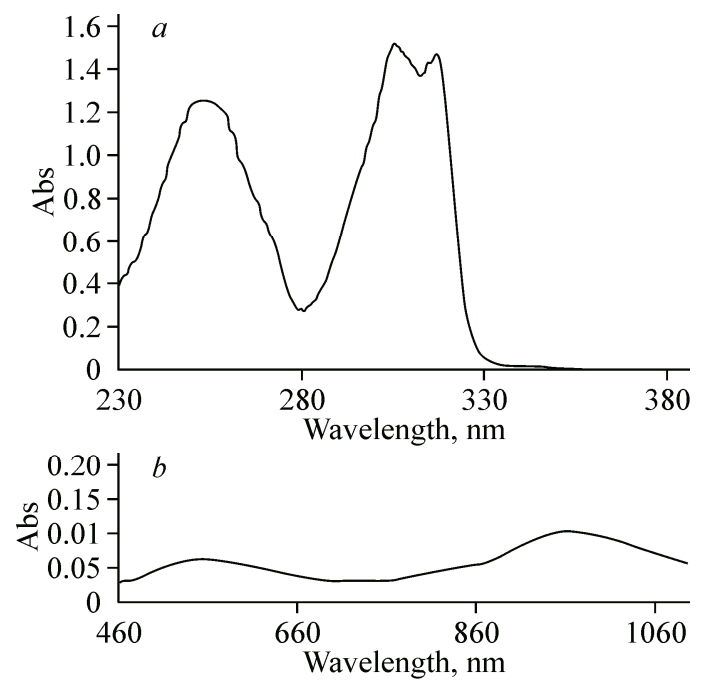

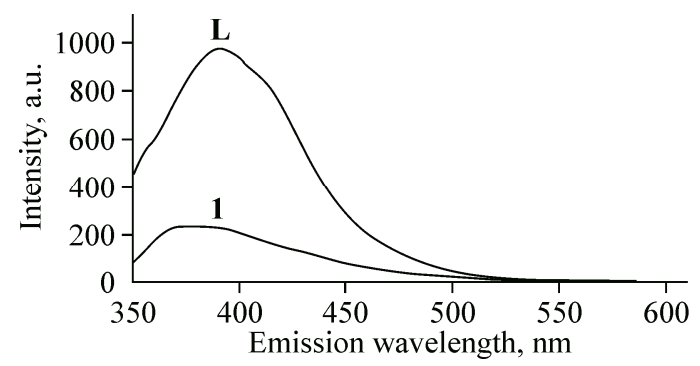

Fig. 1 (left). UV-Vis absorption spectrum of $\mathbf{1}$ $\left(\mathrm{a}, \mathrm{c}=1.15 \times 10^{-5} \mathrm{M}, \mathrm{b}, \mathrm{c}=4.65 \times 10^{-4} \mathrm{M}\right)$ in $\mathrm{CH}_{3} \mathrm{OH}$

Fig. 2 (right). The luminescence spectra of $\mathbf{L}$ $\left(4.52 \times 10^{-3} \mathrm{M}\right)$ and $1\left(4.60 \times 10^{-3} \mathrm{M}\right)$ in $\mathrm{CH}_{3} \mathrm{OH}$ at room temperature; excitation wavelength $=315 \mathrm{~nm}$ 
Crystallographic and structure refinement data for $\mathbf{1}$

Formula
Formula weight
Temperature, $\mathrm{K}$
Wavelength $\lambda, \AA$
Crystal system
Space group
Crystal size, mm
$a, b, c, \AA ; \beta$, deg.
Volume, $\AA^{3}$
$Z$
Density (calc.), g/cm ${ }^{3}$
$\theta$ ranges for data collection
$F(000)$
Absorption coefficient, mm ${ }^{-1}$
Index ranges
Data collected
Unique data $\left(R_{\text {int }}\right)$
Completeness to $\theta, \%$
Parameters, restrains
Final $R_{1}, w R_{2}$ (obs. data)
Final $R_{1}, w R_{2}$ (all data)
Goodness of fit on $F^{2}(S)$
Largest diff peak and hole, e $/ \AA^{3}$

$$
\begin{gathered}
\mathrm{C}_{24} \mathrm{H}_{30} \mathrm{Cl}_{2} \mathrm{~N}_{4} \mathrm{NiO}_{3} \\
552.11 \\
298(2) \\
0.71073 \\
\text { Monoclinic } \\
C 2 / c \\
0.10 \times 0.12 \times 0.22
\end{gathered}
$$

18.1953(17), 14.0261(12), 11.9338(12); 121.689(6)

$$
\text { 2591.6(5) }
$$

4

1.415

$1.96-26.00$

1152

0.987

$-22 \leq h \leq 19,-15 \leq k \leq 17,-14 \leq l \leq 14$

6752

2550, (0.064)

99.8

184,0

$0.0497,0.0834$

$0.0950,0.1027$

1.012

$0.332,-0.268$

$400 \mathrm{~nm}$ is shifted to $376 \mathrm{~nm}$ in complex 1, with blue-shift after coordination to Ni(II) (24 nm blueshifted compared to the related emission band). The similarity of the shapes of the emission spectra of 5,5'-dmbipy and 1 suggests their equal origins, which can be from ligand centered transitions (LC), such as $\pi^{*} \rightarrow \pi$ emission. The observed blue-shift for 1 can be explained by a decrease of the energy gap between the ground and excited states in the 5,5'-dmbipy ligand upon complexation with $\mathrm{Ni}$ (II) [32-35].

Description of the molecular structure of $\left[\mathrm{Ni}\left(5,5^{\prime}-\mathrm{dmbipy}\right)_{2} \mathrm{Cl}_{2}\right] \cdot 3 \mathrm{H}_{2} \mathrm{O}$ (1). Crystallographic data for 1 are given in Table 1 and the selected bond lengths and angles are presented in Table 2. The ORTEP view with the numbering schemes for compound $\mathbf{1}$ is shown in Fig. 3. The asymmetric unit of the title compound contains one half of the crystallographically independent $\left[\mathrm{Ni}\left(5,5^{\prime}-\mathrm{dmbipy}\right)_{2} \mathrm{Cl}_{2}\right]$ molecule and one and half water solvent molecules. In the title complex, the $\mathrm{Ni}$ atom has a distorted octahedral coordination by four $\mathrm{N}$ atoms from two 5,5'-dimethyl-2,2'-bipyridine ligands and two $\mathrm{Cl}^{-}$ anions.

Bond distances $(\AA)$ and bond angles (deg.) for $\mathbf{1}$

\begin{tabular}{l|l|l|r||l|l||l|l}
\hline Ni1-Cl1 & $2.4266(10)$ & Cl1-Ni1-N1 & $96.67(7)$ & C11-Ni1-N2a & $88.80(7)$ & N1-Ni1-N2a & $92.37(11)$ \\
Ni1-N1 & $2.074(3)$ & Cl1-Ni1-N2 & $174.63(9)$ & N1-Ni1-N2 & $78.36(11)$ & N2-Ni1-N2a & $93.42(10)$ \\
Ni1-N2 & $2.109(3)$ & Cl1-Ni1-Cl1a & $89.43(4)$ & N1-Ni1-N1a & $166.57(12)$ & C11a-Ni1-N1a & $96.67(7)$ \\
& & Cl1-Ni1-N1a & $92.87(7)$ & & &
\end{tabular}

Symmetry code: (a) $1-x, y, 1 / 2-z$. 
Fig. 3. The labeled diagram of $\mathbf{1}$ Thermal ellipsoids are at $30 \%$ probability level
Fig. 4. Crystal packing diagram for 1 . Intermolecular $\mathrm{O}-\mathrm{H} \cdots \mathrm{O}, \mathrm{O}-\mathrm{H} \cdots \mathrm{Cl}$, $\mathrm{C}-\mathrm{H} \cdots \mathrm{Cl}$ and $\mathrm{C}-\mathrm{H} \cdots \mathrm{O}$ hydrogen bonds are shown as dashed lines
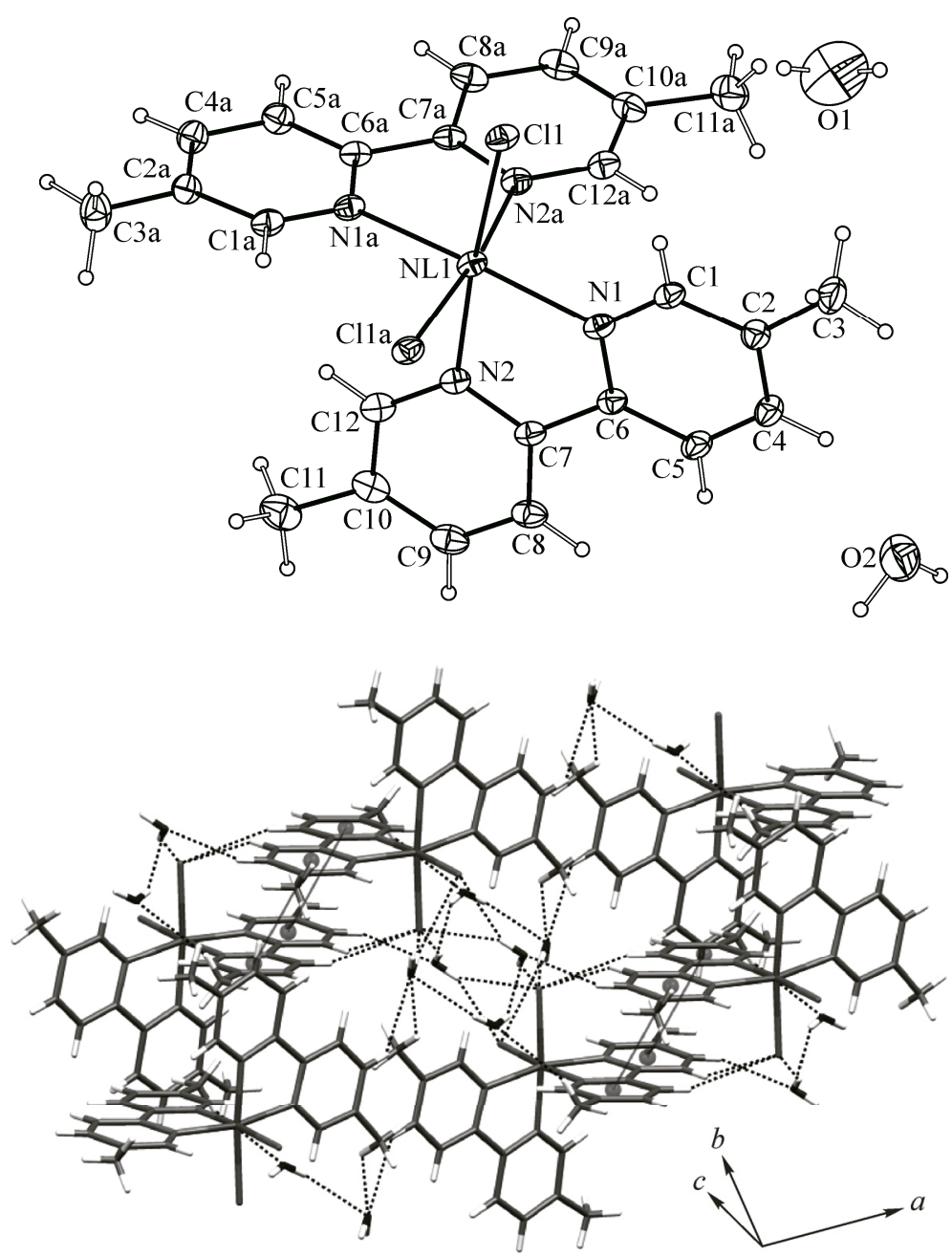

The $\mathrm{Ni}-\mathrm{N}$ bond lengths are 2.074(3) $\AA$ and 2.109(3) $\AA$, and $\mathrm{Ni}-\mathrm{Cl}$ bond length is 2.4266(10) $\AA$ (Table 2). The $\mathrm{Ni}-\mathrm{N}$ and $\mathrm{Ni}-\mathrm{Cl}$ bond lengths and angles are in good agreement with the correspondding values in $\left[\mathrm{Ni}(\text { bipy })_{2} \mathrm{Cl}_{2}\right] \cdot \mathrm{CH}_{3} \mathrm{OH}$ [36]. The pyridine rings in the title complex are slightly distorted from planarity. The mean planes of rings $A(\mathrm{~N} 1 / \mathrm{C} 1-\mathrm{C} 2 / \mathrm{C} 4-\mathrm{C} 6), B(\mathrm{~N} 2 / \mathrm{C} 7-\mathrm{C} 10 / \mathrm{C} 12)$ and $C(\mathrm{Ni1} / \mathrm{N} 1 / \mathrm{C} 6-\mathrm{C} 7 / \mathrm{N} 2)$ make the following dihedral angles with each other: $A / B=5.11^{\circ}, A / C=3.93^{\circ}$ and $B / C=3.18^{\circ}$. This distortion from planarity is due to the steric hindrance caused by the methyl group.

In the crystal structure of complex 1, Fig. 4, it seems that the main factors controlling the packing of the structure are intermolecular $\mathrm{C}-\mathrm{H} \cdots \mathrm{Cl}$ and $\mathrm{C}-\mathrm{H} \cdots \mathrm{O}$ hydrogen bonds (Table 3 ) and $\pi-\pi$ interactions between the pyridine rings, $C g 3 \cdots C g 4^{i}(i=1 / 2-x, 1 / 2-y,-z$; centroid-centroid distance is

T a b l e 3

Hydrogen bond geometry for $\mathbf{1}$ in crystal packing $(\AA$, deg.)

\begin{tabular}{l|l|l|l|l|c}
\hline \multicolumn{1}{c|}{$\mathrm{D}-\mathrm{H} \cdots \mathrm{A}$} & \multicolumn{1}{c|}{$\mathrm{D}-\mathrm{H}$} & \multicolumn{1}{c}{$\mathrm{H} \cdots \mathrm{A}$} & \multicolumn{1}{c|}{$\mathrm{D} \cdots \mathrm{A}$} & $\mathrm{D}-\mathrm{H} \cdots \mathrm{A}$ & Symmetry code \\
\hline $\mathrm{O} 1-\mathrm{H} 1 \mathrm{~B} \cdots \mathrm{O} 2$ & $0.78(8)$ & $2.30(8)$ & $2.977(12)$ & $146(6)$ & $1 / 2-x, 1 / 2-y, 1-z$ \\
$\mathrm{O} 2-\mathrm{H} 2 \mathrm{~A} \cdots \mathrm{C} 11$ & $0.95(10)$ & $2.35(10)$ & $3.243(7)$ & $156(10)$ & $-1 / 2+x, 1 / 2-y,-1 / 2+z$ \\
$\mathrm{O} 2-\mathrm{H} 2 \mathrm{~B} \cdots \mathrm{C} 11$ & $0.80(11)$ & $2.73(12)$ & $3.388(8)$ & $142(10)$ & $1 / 2-x,-1 / 2+y, 1 / 2-z$ \\
$\mathrm{C} 1-\mathrm{H} 1 \cdots \mathrm{C} 11$ & 0.9300 & 2.7800 & $3.410(4)$ & 126.00 & - \\
$\mathrm{C} 4-\mathrm{H} 4 \cdots \mathrm{O} 2$ & 0.9300 & 2.5500 & $3.285(9)$ & 136.00 & -
\end{tabular}


$3.740(2) \AA)[C g 3$ and $C g 4$ are centroids of the rings $(\mathrm{N} 1 / \mathrm{C} 1-\mathrm{C} 2 / \mathrm{C} 4-\mathrm{C} 6)$ and $(\mathrm{N} 2 / \mathrm{C} 7-\mathrm{C} 10 / \mathrm{C} 12)$, respectively].

CCDC 995694 contains the supplementary crystallographic data for $\mathbf{1}$. These data can be obtained free of charge via http://www.ccdc.cam.ac.uk/conts/retrieving.html, or from the Cambridge Crystallographic Data Centre, 12 Union Road, Cambridge CB2 1EZ, UK; fax: (+44) 1223336 033; or e-mail: deposit@ccdc.cam.ac.uk.

The authors are grateful Islamic Azad University, North Tehran Branch and Shahre-Rey Branch, for finansical support.

\section{REFERENCES}

1. Riedel E. Anorganische Chemie, 6th ed., De Gruyter, 2004.

2. Hipler B., Döring M., Dubs C., Görls H., Hübler T., Uhlig E. // Z. Anorg. Allg. Chem. - 1998. - 624. - P. $1329-1335$.

3. Ferbinteanu M., Cimpoesu F., Andruh M., Rochon F.D. // Polyhedron. - 1998. - 17. - P. 3671 - 3679.

4. Małecki J.G., Machura B., Świtlicka A. // Struct. Chem. - 2011. - 22. - P. $77-87$.

5. Ye B.H., Chen X.M., Xue G.Q., Ji L.N. // J. Chem. Soc., Dalton Trans. - 1998. - P. 2827 - 2831.

6. Rujiwatra A., Yimklan S., Prior T.J. // Polyhedron. - 2012. - 31. - P. 345 - 351.

7. Pérez C.R., Lorenzo L.P.A., Lloret F., Julve M. // Inorg. Chim. Acta. - 2002. - 336. - P. 131 - 136.

8. Janiak C., Deblon S., Wu H.P., Kolm M.J., Klüfers P., Piotrowski H., Mayer P. // Eur. J. Inorg. Chem. - 1999. - P. $1507-1521$.

9. Massicot F., Schneider R., Fort Y., Illy-Cherrey S., Tillement O. // Tetrahedron. - 2001. - 57. - P. 531 536.

10. Kinnunen T.J.J., Haukka M., Pakkanen T.T., Pakkanen T.A. // J. Organomet. Chem. - 2000. - 613. - P. 257 262.

11. Amani V., Safari N., Khavasi H.R. // Polyhedron. - 2007. - 26. - P. 4257 - 4262.

12. Amani V., Safari N., Khavasi H.R., Akkurt M. // Polyhedron. - 28. - P. 3026 - 3030.

13. Ostad S.N., Emadi S.M., Tavajohi S., Amani V., Abedi A. // Bull. Korean Chem. Soc. - 2012. - 33, N 11. - P. $3891-3894$.

14. Alizadeh R., Amani V. // Struct. Chem. - 2011. - 22. - P. 1153 - 1163.

15. Alizadeh R., Amani V., Farshady A.A., Khavasi H.R. // J. Coord. Chem. - 2010, - 63. - P. $2122-2131$.

16. Karaca S., Akkurt M., Safari N., Amani V., Büyükgüngör O., Abedi A. // Acta Crystallogr. - 2009. - E65. - P. $\mathrm{m} 335-\mathrm{m} 336$.

17. Ahmadi R., Kalateh K., Amani V. // Acta Crystallogr. - 2010. - E66. - P. m562.

18. Khalighi A., Ahmadi R., Amani V., Khavasi H.R. // Acta Crystallogr. - 2008. - E64. - P. m1211 - m1212.

19. Kalateh K., Ahmadi R., Ebadi A., Amani V., Khavasi H.R. // Acta Crystallogr. - 2008. - E64. - P. m1353 $\mathrm{m} 1354$.

20. Ghiasi Z., Amani V., Mirzaei P., Safari N., Abedi A. // Aust. J. Chem. -2013. - 66. - P. 676 - 684.

21. Perera T., Abhayawardhana P., Fronczek F.R., Marzilli P.A., Marzilli L.G. // Eur. J. Inorg. Chem. - 2012. - P. $618-627$.

22. Phatchimkun J., Kongsaeree P., Suchaichit N., Chaichit N. // Acta Crystallogr. - 2009. -E65. - P. m1020 m1021.

23. Sheldrick G.M. SADABS, Bruker AXS. - Madison, WI, USA, 1998.

24. Bruker SMART and SAINT. Bruker AXS Inc. - Madison, WI, USA, 1998.

25. Sheldrick G.M. // Acta Crystallogr. - 2008. - A64. - P. 112 - 122.

26. Mercury 1.4.1. Copyright Cambridge Crystallographic Data Center, 12 Union Road, Cambridge CB2 1EZ, UK, 2001-2005.

27. Amani V., Safari N., Khavasi H.R. // Polyhedron. - 2007. - 26. - P. 4257 - 4262.

28. Nakamoto K. Infrared and Raman spectra of inorganic and coordination compound, Part B: Application in coordination, organometallic and bioinorganic chemistry. - New York: John Wiley and Sons Inc., 2009.

29. Amani V., Safari N., Khavasi H.R., Mirzaei P. // Polyhedron. - 2007. - 26. - P. 4908 - 4914.

30. Amani V., Safari N., Notash B., Khavasi H.R. // J. Coord. Chem. - 2009. - 62. - P. $1939-1950$.

31. Harris C.M., McKenzie E.D. // J. Inorg. Nucl. Chem. - 1967. - 29. - P. 1047 - 1068.

32. Abedi A., Safari N., Amani V., Khavasi H.R. // J. Coord. Chem. - 2012. - 65. - P. 325 - 338.

33. Abedi A., Amani V., Safari N. // Main Group Chem. - 2012. - 11. - P. 223 - 233.

34. Liu S.G., Zuo J.L., Li Y.Z., You X.Z. // J. Mol. Struct. - 2004. - 705. - P. 153 - 157.

35. Modi C.K., Jani D.H., Patel H.S., Pandya H.M. // Spectrochim. Acta, Part A. - 2010. - 75. - P. 1321 1328.

36. Fontaine F.G. // Acta Crystallogr. - 2001. - E57. - P. m270 - m271. 